\title{
A Shielded Storage and Processing Facility for Radioisotope Thermoelectric Generator Heat Source Production
}

Prepared for the U.S. Department of Energy Assistant Secretary for Nuclear Energy

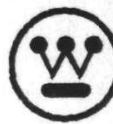

Westinghouse

Hanford Company Richland, Washington

Hanford Operations and Engineering Contractor for the U.S. Department of Energy under Contract DE-AC06-87RL10930 Copyright License By acceptance of this article, the publisher and/or recipient acknowledges the U.S. Government's right $6 \mathrm{LP}$
retain a nonexclusive, royalty-free license in and to any copyright covering this paper.

DISTRIBUTION OF THIS DOCUMENT IS UNLIMITIED Approved for Public Release

$$
\leq 0
$$




\section{DISCLAIMER}

This report was prepared as an account of work sponsored by an agency of the United States Government. Neither the United States Government nor any agency Thereof, nor any of their employees, makes any warranty, express or implied, or assumes any legal liability or responsibility for the accuracy, completeness, or usefulness of any information, apparatus, product, or process disclosed, or represents that its use would not infringe privately owned rights. Reference herein to any specific commercial product, process, or service by trade name, trademark, manufacturer, or otherwise does not necessarily constitute or imply its endorsement, recommendation, or favoring by the United States Government or any agency thereof. The views and opinions of authors expressed herein do not necessarily state or reflect those of the United States Government or any agency thereof. 


\section{DISCLAIMER}

Portions of this document may be illegible in electronic image products. Images are produced from the best available original document. 


\section{LEGAL DISCLAIMER}

This report was prepared as an account of work sponsored by an agency of the United States Government. Neither the United States Government nor any agency thereof, nor any of their employees, nor any of their contractors, subcontractors or their employees, makes any warranty, express or implied, or assumes any legal liability or responsibility for the accuracy, completeness, or any third party's use or the results of such use of any information, apparatus, product, or process disclosed, or represents that its use would not infringe privately owned rights. Reference herein to any specific commercial product, process, or service by trade name, trademark, manufacturer, or otherwise, does not necessarily constitute or imply its endorsement, recommendation, or favoring by the United States Government or any agency thereof or its contractors or subcontractors. The views and opinions of authors expressed herein do not necessarily state or reflect those of the United States Government or any agency thereof.

This report has been reproduced from the best available copy.

Printed in the United States of America

DISCLM-2.CHP (1-91) 


\title{
A Shielded Storage and Processing Facility for Radioisotope Thermoelectric Generator Heat Source Production
}

\author{
D. L. Sherrell
}

Date Published

June 1992

To Be Presented at 10 th Symposium on Space Nuclear Power and Propulsion Albuquerque, New Mexico January 10-14, 1993

Prepared for the U.S. Department of Energy Assistant Secretary for Nuclear Energy

$\begin{array}{ll}\text { Westinghouse } & \text { P.O. Box } 1970 \\ \text { Hanford Company } & \text { Richland, Washington } 99352\end{array}$

Hanford Operations and Engineering Contractor for the

U.S. Department of Energy under Contract DE-AC06-87RL10930

Copyright License By acceptance of this article, the publisher and/or reciprent acknowledges the U.S. Government's right to retan a nonexclusive, royalfy-free license in and to any copynght covering this paper. 


\title{
A SHIELDED STORAGE AND PROCESSING FACILITY FOR RADIOISOTOPE THERMOELECTRIC GENERATOR HEAT SOURCE PRODUCTION
}

\author{
Dennis L. Sherrell \\ Westinghouse Hanford Company \\ P.O. Box 1970, $\mathrm{N} 1-42$ \\ Richland, WA 99352
}

(509) $376-2190$

\begin{abstract}
A shielded storage rack has been installed as part of the Radioisotope Power Systems Facility (RPSF) at the U.S. Department of Energy's (DOE) Hanford Site in Washington State. The RPSF is designed to replace an existing facility at DOE's Mound Site near Dayton, Ohio, where General Purpose Heat Sourco (GPHS) modules are currently assembled and installed into Radioisotope Thermoelectric Generators (RTG). The overall design goal of the RPSF is to increase annual production throughput, while at the same time reducing annual radiation exposure to personnel. The shield rack design successfully achieved this goal for the Module Reduction and Monitoring Facility (MRMF), which processes and stores assembled GPHS modules, prior to their installation into RTGs. The shield rack design is simple and effective, with the result that background radiation levels within Hanford's MRMF room are calculated at just over three percent of those typically experienced during operation of the existing MRMF at Mound, despite the fact that Hanford's calculations assume five times the GPHS inventory of that assumed for Mound.
\end{abstract}

\section{INTRODUCTION}

The RPSF is currently being installed within the Fuels and Materials Examination Facility (FMEF), located on DOE's Hanford Site in Washington State. The RPSF project expands DOE's RTG production capacity and provides for eventual replacement of an existing RTG assembly operation, currently located at DOE's Mound Site, near Dayton, Ohio. The RPSF includes all functions necessary to receive, inspect, store, assemble, test, and ship RTGs and RTG components.

Following their assembly within the RPSF hot cells, GPHS modules will be packed into stainless steel cans and transferred to the MRMF room for processing to remove excess oxygen. Upon completion of the processing, they will be transferred to an adjacent room and installed into thermoelectric generators.

\section{DESCRIPTION}

Hanford's MRMF (Figure 1) will consist of three shielded storage racks, a remotely operated evacuate and backfill system, and a remotely operated trace gas analysis system. This equipment is being installed on the first level below grade, within an isolated room near the northwest comer of the FMEF building. The MRMF room is adjacent to several other rooms that will be used for RTG assembly and testing. Each shield rack (Figure 2) is designed to accommodate 32 MRMF cans, containing 2 GPHS modules each, in horizontal shield wells. The MRMF cans will be installed at the inboard end of each horizontal well via an insulated shield plug assembly (Figure 3). All shield plug assemblies will be served by a single insertion fixture (Figure 4).

\section{DISCUSSION}

\section{Module Reduction and Monitoring Facility Process}

Completed RTGs must be internally pressurized with inert cover gas to prevent harmful atmospheric gases from seeping in through containment seals and damaging solid state components. Unfortunately, any excess oxygen within the plutonium oxide fuel matrix or other GPHS components will still cause two harmful gasses 
Figure 1. Module Reduction and Monitoring Facility Equpment Arrangement.

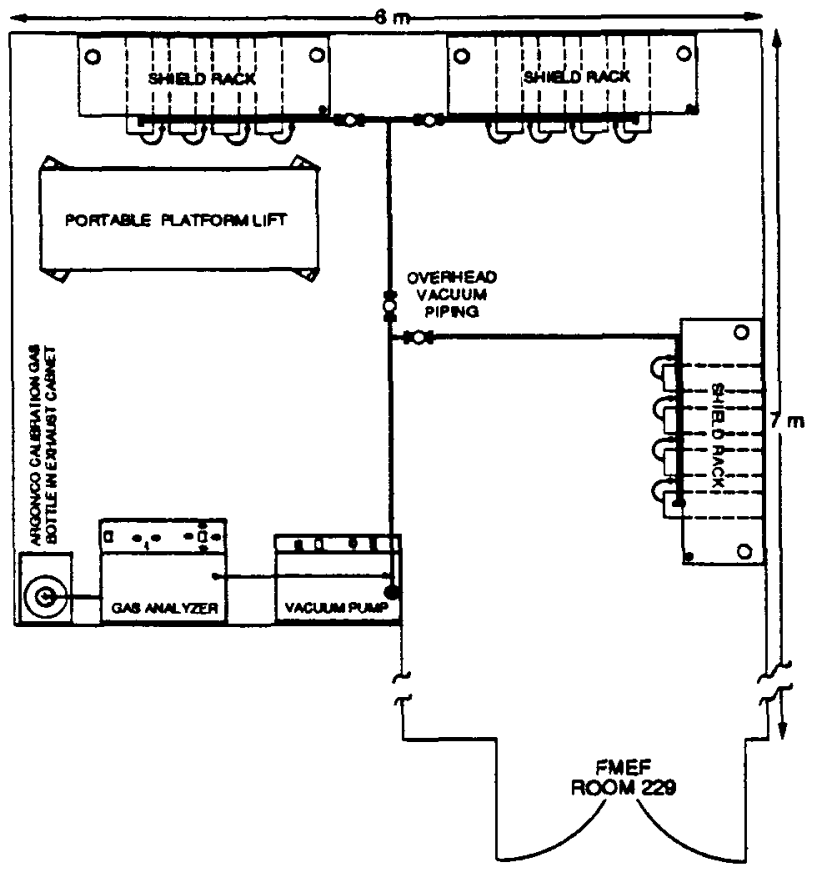

Figure 2. Shield Rack Installation.

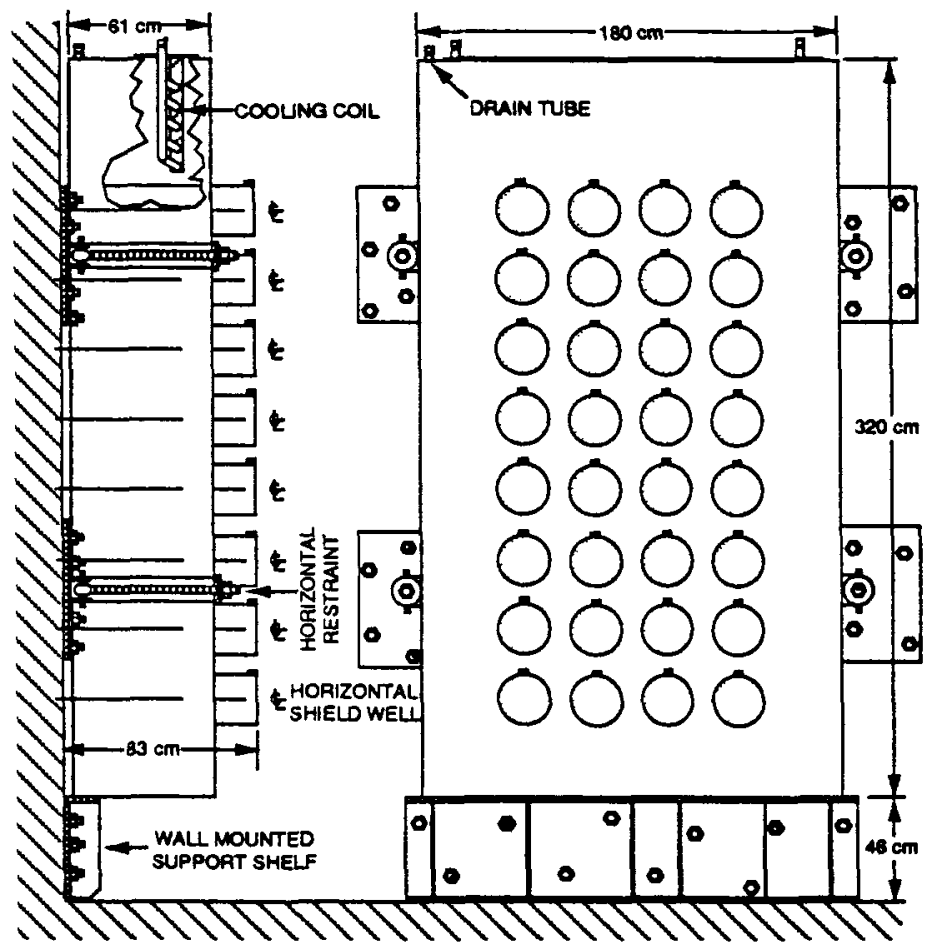


WHC-SA-1594-FP

Figure 3. Sheid Plug.



Figure 4. Shield Plug Insertion Fixture.




(carbon monoxide and carbon dioxide) to build into the cover gas. The mechanism behind this has been described along the following lines (Johnson 1982). Under typical RTG storage conditions, graphite GPHS components introduce a small amount of carbon monoxide into the inert cover gas within the RTG's case. The carbon monoxide diffuses into the fuel matrix, where it combines with oxygen to produce carbon dioxide, fractionally reducing the ratio of oxygen to metal atoms within the sintered metal-oxide fuel matrix. The carbon dioxide migrates back to the graphite, where it reacts with the carbon to produce twice as much carbon monoxide, and so on. The object of the MRMF process is to use this same mechanism (albeit a problem within completed RTGs) to reduce the oxygen-to-metal ratio of the fuel matrix down to a point where the metal atoms bond oxygen tightly enough to limit carbon dioxide production to acceptable levels before the GPHS modules are installed into the RTG.

The MRMF process actually begins in the GPHS assembly area, where completed GPHS modules are packed (two at a time) into stainless steel cans. The surrounding carbon-fiber felt packing material acts as an insulating blanket, increasing GPHS component temperatures to a value that falls between their prelaunch storage temperatures and their (higher) postlaunch operating temperatures. At these elevated storage temperatures, the various exchange reactions run faster and proceed further than they would at normal storage temperatures.

\section{Module Reduction and Monitoring Facility Operations}

Following GPHS packing, lid welding, and leak testing operations within the RPSF hot cells, MRMF cans will be placed into a shielded transport vehicle, and moved up one floor to the MRMF room. Prior to arrival of the transport vehicle within the isolated MRMF room, a self-powered lift platform will be stationed in front of the shield rack, and the shield plug insertion fixture will be installed on the target shield rack location. Upon arrival of the transport cart: 1) the shield plug will be withdrawn by a motor-driven jack screw, which will be controlled by an operator standing on the far end of the 2-m long portable lift platform; 2) the platform operator will step over to the withdrawn shield plug and remove a one-piece can cover/hose retainer bar assembly from the shield plug (Figure 3), and set it aside; 3) the transport cart operator will use a 2-m long grappling tool to remove the MRMF can from the transport cart, and hand it (via the grappling tool) up to the lift platform operator; 4) the transport cart operator will immediately step back to the doorway, where radiation levels will be negligible; 5) the platform operator will insert the can into the shield piug, dress the bose into a channel at the top of the shield plug, and reinstall the can cover/hose retainer bar assembly; 6) the platform operator will step back to the far end of the platform and activate the shield plug insertion motor; 7) the platform operator will remove the shield plug insertion fixture; 8) the platform operator will connect the can's hose-block valve assembly to the MRMF manifold valve; and 9) the quality control inspector will enter the room, climb onto the platform, confirm proper connection of the can, and exit the room.

Once a particular can has been installed within the RPSF shield rack and connected to the evacuate and backfill manifold, all operating personnel will leave the room. The processing and monitoring operations will be performed remotely. Depending on a number of GPHS production variables, MRMF processing may require anywhere from 2 weeks to 3 months. The processing is considered complete when three consecutive cover gas analyses, taken 1 week apart, confirm acceptable carbon monoxide/carbon dioxide levels. The cans then continue to be stored and monitored within the MRMF, pending their transfer to the RTG assembly area.

\section{Module Reduction and Monitoring Facility Room}

The MRMF is located in Room 229, on the second building level below grade. This is an L-shaped, isolated room, with approximately $25 \mathrm{~m}^{2}$ of floor space in the main area and $7.5 \mathrm{~m}^{2}$ of staging area, just inside the doors. Although each shield rack is designed to accommodate $32 \mathrm{MRMF}$ cans, containing 2 GPHS modules each, the total MRMF room inventory will be limited to 184 GPHS modules, based on a worst case criticality scenario wherein all 184 modules are removed from their respective cans and neatly stacked in a corner of the room. Worst case background radiation dose rates for the fully loaded MRMF are calculated to fall below $3 \mathrm{mrem} / \mathrm{hr}$, which is weil under the current DOE criteria for posting the room as a radiation area ( $>5 \mathrm{mrem} / \mathrm{hr}$ ). However, Westinghouse Hanford's criteria require that the MRMF room be a l-hr/d, limited occupancy area. 
The 320-cm-high, by $180-\mathrm{cm}$-wide, by $61-\mathrm{cm}$-deep shieid rack tank structures are weld fabricated from 1-cm-thick, austenitic stainiess steel plate. Thirty-two each, 21-cm-diameter by 79-cm-long, austenitic stainless steel horizontal storage wells are welded, tube sheet fashion, into the front and back walls of each tank structure. The outboard end of each horizontal well protrudes $18 \mathrm{~cm}$ beyond the front wall of the tank structure. The inboard end is installed flush with the back wall.

Neutron and gamma shielding are provided by over $2700 \mathrm{~kg}$ of plain water (i.e., unborated) contained within each tank structure, and by a $42-\mathrm{cm}$-long cast refractory plug within the outboard end of the shield piug assembly. Additional gamma shieiding is provided by the tank walls, and by an 8 -cm-thick, carbon steel shadow shield disk, located directly in front of each can. Each shield plug has a can compartment at its inboard end, fitted with thin stainiess steel standoffs to provide a $2.5-\mathrm{cm}$ radial air gap between the outside of the can and the inside of the shield plug tube. This air gap may also be filled with insulating or beat conducting materials, depending on the processing requirements. In addition to similar axial air gaps, the inboard and outboard ends of the can compartment are provided with $2.5-\mathrm{cm}$-thick, axial insulation blankets. The shield rack located against the interior (east) room wall depends on the $76-\mathrm{cm}$-thick concrete interior room wall to absorb neutron and gamme radiation from the inboard ends of its cans. The two shield racks located against the north room wall are adequately supplied with both concrete and fill dirt to absorb radiation from the inboard ends of their cans, since that is an external building wall, located well below grade. The shielding calculations indicate that existing interior structural concrete floors, walls, and steel security doors, in combination with the physical separation afforded by the room layout, will be sufficient to limit radiation levels in adjacent building areas to Westinghouse Hanford's full time occupancy criteria for nuclear process areas $(<0.2 \mathrm{mrem} / \mathrm{hr}$ ).

\section{Design Strategy}

The shielding design effort was complicated by the need to accommodate a large inventory of high-dose-rate, high-heat-load material. The foundation design was, in turn, complicated by the large mass and size of the shielding.

To achieve design goals it was necessary to iterate design and analysis activities in three separate disciplines: 1) shielding design and analysis, to maintain the combined dose from room entry and subsequent canister handling activities as low as reasonably achievable; 2) structural design and analysis, to accommodate heavy loads imposed on critical DOE Safety Class building structures by the shield racks; and 3) thermal-hydraulic design and analysis, to accommodate large decay heat loads concentrated within the shield racks.

\section{Process Cooling Design}

The primary neutron shielding material in the MRMF is water, instead of concrete or polyethylene, because the water can also provide process cooling. The resulting thermal-hydraulic design is both simple and effective, with a capability to reject $50 \mathrm{~kW}$ of radioactive decay heat to the building cooling water system via natural convection of the shielding water. Each shield rack has an austenitic stainless steel cooling coil assembly installed at the upper end of its tank structure (Figure 2), providing roughly $1.5 \mathrm{~m}^{2}$ of heat transfer area. Each coil assembly is supplied with $0.5 \mathrm{~kg} / \mathrm{s}$ of forced cooling water flow to carry away over $16 \mathrm{~kW}$ of decay heat per shield rack. In the event that the building's main, forced-flow cooling water system fails, an emergency system automatically picks up the load. The calculated maximum operating temperature of the shield rack structure is $54^{\circ} \mathrm{C}$, with only a few degrees of top-to-bottom differential required to maintain the convection flow. Conservative calculations, which assume no heat loss to the room, also indicate that shield water would still surround all of the canister positions following total loss of both normal and emergency cooling water flow through the coils for $12 \mathrm{hr}$, although it would be boiling. Even then, only $26 \mathrm{~kg}$ of make up water would need to be added each hour to maintain coverage of all can positions. Based on the conservative boiling water assumption, the calculations indicate that the MRMF cans, the GPHS modules, and the fuel capsules which they contain would still retain their integrity. A stainless steel pipe, penetrating the top of each shield rack's tank structure, and terminating near the tank bottom, serves as a drain connection. During normal operation this 
connection is capped off to eliminate any possibility for loss of the shielding/cooling water through syphoning. Shielding water will be added to the tank via a $10-\mathrm{cm}$-diameter opening in the top plate, eliminating any requirement for direct connection of the tank structure to potable water systems. The opening will not be sealed with a flange, but will instead be loosely covered by a piece of foam glass material. An electronic level transmitter with remote high-level and low-level alarm functions is also provided.

\section{Shield Rack Foundation Design}

Because the total mass of each fully loaded shield rack will exceed 7 metric tons, and because the floor load capacity in Room 229 is very limited, the shield racks are supported entirely by the room walls on shelves and horizontal restraint anchors, tied into the walls via drilled-in expansion bolts. The MRMF is designated as a DOE Non-Safety Class over DOE Safety Class installation, and has therefore been subjected to a design basis earthquake (DBE) dynamic analysis.

\section{Shielding Design}

The MRMF shielding criteria (based on an inventory of 184 GPHS modules, each containing $112 \mathrm{~g}$ of 3-yr-old ${ }^{238} \mathrm{Pu}$ fuel, contaminated with $2 \mathrm{ppm}$ of ${ }^{236} \mathrm{Pu}$ ) set the average room background radiation goal at $2.0 \mathrm{mrem} / \mathrm{hr}$. This is appropriate to an isolated Hanford facility with a $1 \mathrm{hr} / \mathrm{d}$ maximum occupancy limit. While this is above Hanford's $0.2-\mathrm{mrem} / \mathrm{hr}$ design goal for full time occupancy nuclear process areas, the resulting shielding design strikes a good balance between the dose absorbed while working at room background dose rates, and the dose absorbed while the cans are being installed into the shield plugs.

In addition to meeting the $2.0-\mathrm{mrem} / \mathrm{hr}$ average room background radiation goal, detailed calculations establish the maximum dose rate at shield rack working faces as $3.0 \mathrm{mrem} / \mathrm{hr}$ (based on a fully loaded MRMF with all shield plugs in place). On the other hand, it has been necessary to make some conservative assumptions in order to establish working times at the various dose rates that will prevail during each of the MRMF can installation steps. Based on all of the above, installation of the very last can into the otherwise fully loaded MRMF room is expected to contribute about 4 mrem to RPSF's total integrated personnel dose, while installation of the very first can into an otherwise empty MRMF room is expected to contribute only 1 mrem. Both of these estimates include an allowance of $1 / 2 \mathrm{mrem}$ for maintenance activities within the MRMF room, and both assume a neutron quality factor of 20 . Because each handling operation must be performed twice for each can processed through the MRMF, and because each can contains two GPHS modules, the above dose range per can also is the expected dose range per GPHS module (i.e., 1 to $4 \mathrm{mrem}$ ). Because there are no Hanford Site calculations available for anything other than a fully loaded MRMF (184 GPHS modules), the average per-module dose is here estimated as the simple arithmetic mean of the best and worst cases: $(1.0+$ $4.0) / 2=2.5 \mathrm{mrem}$ per GPHS module processed. In rough terms, this means that Hanford's MRMF is capable of operating with over five times the total fuel inventory typical in the past, while at the same time producing only one-fourth the total integrated personnel dose per GPHS module than would be expected to accrue with any preexisting facility design.

\section{CONCLUSIONS}

The shield rack design is simple and effective, limiting background radiation levels within Hanford's MRMF room to just over three percent of those typical of the existing Mound Site operation. The expected bottom line is a factor of four reduction in the total integrated radiation dose to personnel from each GPHS module processed through the MRMF. This applies despite the dose comparison's assumption that Hanford's MRMF will contain 5 times as much inventory (184 GPHS modules) as that assumed for the Mound Site's MRMF (36 GPHS modules--i.e., a 2 RTG fuel complement).

\section{ACKNOWLEDGEMENTS}

Because Hanford's MRMF design resulted from the efforts of many Westinghouse Hanford personnel, working in many different disciplines, it would be unfair to name just a few. 
WHC-SA-1594-FP

\section{REFERENCES}

Johnson, E. W., 1982, The Behavior of Oxygen Partial Pressure Over Slightly Substoichiometric Plutonia at $1410 \mathrm{~K}$, MLM-2980 UC-4, Monsento Research Corporation, Mound Facility, Miamisburg, Ohio, August 31, 1982. 
WHC-SA-1594-FP

\section{DISTRIBUTION}

Number of copies

ONSITE

4

Westinghouse Hanford Company

D. L. Sherrell

Document Processing

and Distribution (2)

Information Release

Administration

$\mathrm{N} 1-42$

L8-15

L8-07

Distr-1 